\title{
森林計画学会 異動連絡表
}

\begin{tabular}{|c|c|}
\hline$\square$ 連 絡 事 項 & 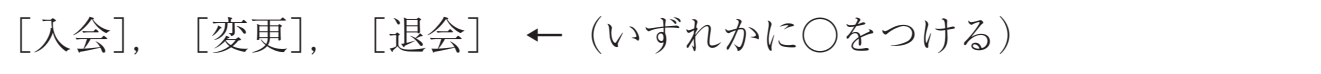 \\
\hline$\square$ 連 絡 年 月 日 & $\begin{array}{lll}\text { 年 } \quad \text { 月 } \quad \text { 日 }\end{array}$ \\
\hline $\begin{array}{cccc}\text { フ } & \text { リ } & \text { ガ } & \text { ナ } \\
\text { 氏 } & & & \text { 名 }\end{array}$ & \\
\hline$\square$ 勤務先 機 関 名 & \\
\hline $\begin{array}{c}\square \text { 連 絡 先 住 所 } \\
\text { (会誌等送付先) }\end{array}$ & [勤務先 $], \quad$ [自宅 $] \leftarrow$ （いずれかに○をつける） \\
\hline $\begin{array}{l}\text { ※郵便物が確実に届くよ } \\
\text { うに正確に書いてくだ } \\
\text { さい。 }\end{array}$ & $\begin{array}{l}\text { 電 話 : } \\
\text { FAX : } \quad(\end{array}$ \\
\hline$\square$ メールアドレス & @ \\
\hline$\square$ 会 員 種 別 & [正会員 $],[$ 学生会員 $],[$ 機関会員 $]$, [購読会員 $] \leftarrow$ (いずれかに○をつける) \\
\hline $\begin{array}{l}\text { 学生 会員の場 合 } \\
\text { (ポスドクなど, 非正規な } \\
\text { 雇用形態にある者を含む) }\end{array}$ & $\begin{array}{l}\text { 卒業予定年月もしくは雇用契約期限： 年（ } \\
\text { 保証人氏名： } \\
\text { 保証人機関名： } \\
\text { 保証人メールアドレス： } \\
\text { (保証人とは学生会員の身分を確認できる正会員もしくは機関会員です) }\end{array}$ \\
\hline 機関会員の場合 & 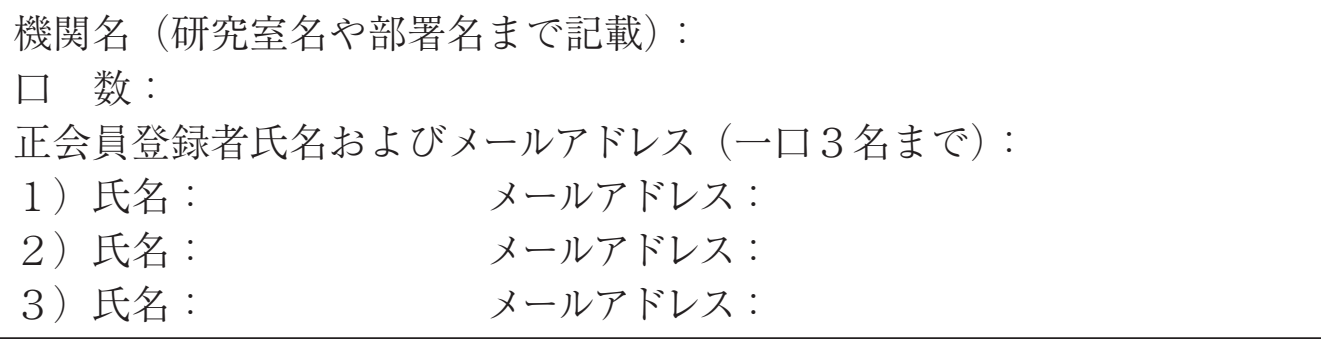 \\
\hline
\end{tabular}

本学会に入会を希望される方，もしくは上記のいずれかの項目に変更があった場合は，この連絡票のす べての項目に記入し，学会事務局までお送りください。変更があった項目の $\square$ 印にチェックをしてください。

送付方法は, 郵送, Fax, 電子メールのいずれでも結構です。電子メールの場合には連絡票を添付ファイ ルとして送付ください。連絡票のファイルは学会ホームページ（http://www.shinrinkeikaku.org/）からダ ウンロードできます。

年会費：正会員８,000円

学生会員筫生会員とは学籍を持つ者および非正規な雇用形態にある者です）

購読会員 和文誌 10,000 円 英文誌 5,000円（機関が対象です）

機関会員 30,000 円 $/$ 一口 (一口 3 名までの正会員登録が可能)

郵便振替口座番号：02230-8-37644＼cjkstart加入者名：森林計画学会

森林計画学会事務局：干812-8581 福岡県福岡市東区箱崎6-10-1 九州大学農学部内

FAX: 092-642-2867

e-mail: jsfp_pr@ffpri.affrc.go.jp 